\title{
Evaluasi tingkat kebergunaan aplikasi Administrasi Penduduk menggunakan teknik System Usability Scale
}

\author{
Usman Ependi a, Ade Putra ${ }^{b}$, Febriyanti Panjaitan ${ }^{c}$ \\ a,c Teknik Informatika, Universitas Bina Darma, Palembang, Indonesia \\ ${ }^{b}$ Komputerisasi Akuntansi, Universitas Bina Darma, Palembang, Indonesia \\ email:au.ependi@binadarma.ac.id, bade.putra@binadarma.ac.id, cfebriyanti_panjaitan@binadarma.ac.id
}

\begin{tabular}{l}
\hline I N F O A R T I K E L \\
\hline Sejarah artikel: \\
Menerima 5 Januari 2019 \\
Revisi 15 April 2019 \\
Diterima 15 April 2019 \\
Online 29 Mei 2019 \\
\hline Kata kunci: \\
administrasi desa \\
kebergunaan \\
System Usability Scale \\
\hline
\end{tabular}

Keywords:

village administration

System Usability Scale usability

\footnotetext{
Style APA dalam menyitasi artikel ini:

Ependi, U., Putra, A., \&

Panjaitan, F. (2019). Evaluasi

tingkat kebergunaan

aplikasi Administrasi

Penduduk menggunakan

teknik System Usability

Scale. Register: Jurnal Ilmiah

Teknologi Sistem Informasi,

5(1), 63-76.
}

\begin{abstract}
ABSTRAK
Kebergunaan (usability) adalah salah satu faktor penting dalam sebuah aplikasi. Saat ini, Dinas Pemberdayaan Masyarakat Desa (PMD) Kabupaten Ogan Ilir telah menyediakan aplikasi administrasi penduduk desa sebagai usaha untuk mencapai tertib administrasi, terutama berkaitan dengan data penduduk. Untuk itu, penelitian ini mengusulkan evaluasi tingkat kebergunaan aplikasi dengan teknik System Usability Scale untuk melihat kelayakan aplikasi yang disediakan untuk digunakan. System usability scale memiliki sepuluh pernyataan sebagai instrumen evaluasi dan tiga indikator penilaian, yaitu acceptability, grade scale, dan adjective rating. Masing-masing pernyataan menjadi indikator untuk melihat tingkat kebergunaan aplikasi. Hasil evaluasi menunjukkan bahwa mayoritas responden dapat memanfaatkan aplikasi dengan baik yang dibuktikan dari nilai rerata setiap pernyataan $>3$. Selain itu, aplikasi administrasi penduduk desa juga dapat dikategorikan sebagai excellent serta berada pada grade $\mathrm{B}$ dengan nilai akhir 88,5 .
\end{abstract}

\section{ABSTRACT}

Usability is one of the most important factors of an application. Currently, the PMD Office of Ogan Ilir District has provided villages with administrative applications as an effort to achieve administration order and boost its effectiveness while analyzing population data. This research evaluates the usability and feasibility levels of applications using the scale system technique. This consists of ten statements as an evaluation instrument with acceptability, grade scale, and adjective rating used as test indicators. The evaluation results shows, that majority of respondents argue that the application is easily proven from the mean score of each statement $>3$. In addition, the village administration application is in very good category and it is in grade B with a final score of 88.5 .

(c) 2019 Register: Jurnal IImiah Teknologi Sistem Informasi. Semua hak cipta dilindungi undang-undang.

\section{Pendahuluan}

Desa adalah bagian penting dalam proses pembangunan yang dilakukan pemerintah Republik Indonesia (RI). Kondisi tersebut sesuai dengan kewenangan yang dimilikinya, yaitu: 1) penyelenggaraan pemerintahan, 2) pemberdayaan masyarakat, 3) pembinaan masyarakat, dan 4) pengelolaan hak asal usul adat istiadat (Indonesia, 2014). Desa saat ini telah mendapatkan alokasi dana khusus dari Anggaran Pendapatan dan Belanja Negara (APBN) yang dikenal dengan dana desa. Setiap desa mendapatkan alokasi dana dengan pagu yang berbeda-beda sesuai dengan tipe dan keadaan desa (RI, 2017). Untuk memastikan dana desa digunakan tepat sasaran, pemerintah telah melakukan berbagai hal, di antaranya penyediaan aplikasi keuangan desa. Aplikasi keuangan desa ini disediakan pemerintah melalui Kementerian Keuangan Republik Indonesia (Kemenkeu RI).

Dinas Pemberdayaan Masyarakat dan Desa (PMD) merupakan perpanjangan tangan Kementerian Keuangan dalam membina desa dan perangkatnya berkaitan dengan pelaporan keuangan di kabupaten. Kondisi tersebut juga dilakukan oleh Dinas PMD Kabupaten Ogan Ilir di Provinsi Evaluasi tingkat kebergunaan aplikasi Administrasi Penduduk menggunakan ... $\quad$ http://doi.org/10.26594/register.v5i1.1412 (C) 2019 Register: Jurnal IImiah Teknologi Sistem Informasi. Semua hak cipta dilindungi undang-undang. 
Sumatra Selatan. Saat ini, Dinas PMD Kabupaten Ogan Ilir memiliki program kerja yang lebih luas, yaitu menjadikan desa tertib administrasi, terutama berkaitan dengan data penduduk. Tertib administrasi penduduk menjadi fokus Dinas PMD Kabupaten Ogan Ilir disebabkan beberapa alasan, di antaranya: 1) kebutuhan data penduduk real di sebuah desa, 2) keadaan penduduk tidak tetap, 3) pemetaan keadaan penduduk, 4) kebutuhan data pemilih yang akurat, dan 5) pelayanan administrasi sesuai data kependudukan (Darmawan, 2018). Untuk melakukan tertib administrasi tersebut, Dinas PMD Kabupaten Ogan Ilir telah menyosialisasikan sebuah aplikasi administrasi penduduk. Aplikasi administrasi penduduk ini disediakan bagi perangkat desa agar dapat melakukan berbagai hal terkait dengan data kependudukan, di antaranya: 1) penambahan data penduduk, 2) pencetakan data penduduk, 3) pencetakan laporan kartu keluarga, 4) pencetakan laporan data pemilih tetap desa, 5) pencatatan dan pelaporan produk unggulan desa, dan 6) pengelolaan data administrasi umum desa.

Untuk itu, sebagai jaminan bahwa aplikasi yang disediakan telah sesuai dengan kebutuhan pengguna (perangkat desa), perlu dilakukan evaluasi. Evaluasi juga dilakukan untuk memastikan tidak adanya keterpaksaan dalam menggunakan aplikasi yang disebabkan aplikasi tidak memiliki nilai usability yang baik. Kondisi tersebut dapat saja terjadi mengingat aplikasi yang disediakan bersifat top down atau disediakan Dinas PMD Kabupaten Ogan Ilir untuk perangkat desa. Sesuai kondisi tersebut, maka evaluasi perlu untuk dilakukan. Selain itu, evaluasi aplikasi juga dilakukan sebagai tindak lanjut dari proses sosialisasi aplikasi administrasi penduduk desa agar mendapatkan umpan balik bagi penyedia aplikasi. Evaluasi aplikasi dapat dilakukan dengan cara uji usability atau kebergunaan. Usability adalah metode evaluasi untuk melihat tingkat kemudahan penggunaan aplikasi (Nielsen, 2012). Usability merupakan salah satu faktor penting dalam sebuah aplikasi sebagai aspek penerimaan aplikasi bagi pengguna (Nurhadryani, Hermadi, \& Khotimah, 2013). Untuk melakukan evaluasi usability dapat dilibatkan ahli ataupun pengguna dari aplikasi yang dihasilkan (Susilo, Wiraatmaja, \& Al Fatta, 2017). Evaluasi usability juga dapat dilakukan terhadap berbagai macam perangkat lunak, baik berbasis mobile, web, desktop, dan berbagai macam platform (Pudjoatmodjo \& Wijaya, 2016). Secara umum, dalam melakukan evaluasi usability terdapat lima macam komponen yang dilihat, yaitu: 1) learnability, 2) efficiency, 3) memorability, 4) errors, dan 5) satisfaction (Xie, Chen, Li, \& Xiong, 2011).

System usability scale (SUS) merupakan salah satu metode usability untuk melakukan evaluasi aplikasi yang melibatkan pengguna akhir (end user) (Martoyo \& Falahah, 2015). SUS memiliki beberapa kelebihan, di antaranya adalah 1) proses evaluasi lebih mudah dimengerti oleh responden, 2) dapat melibatkan sampel yang sedikit tetapi dapat menggambarkan hasil yang maksimal, dan 3) dapat membedakan dengan jelas antara aplikasi yang dapat dan tidak dapat digunakan (usability.gov, 2018). SUS juga memiliki instrumen cara perhitungan yang jelas dalam melakukan evaluasi aplikasi. Dengan demikian, nilai evaluasi yang dihasilkan memiliki nilai kebenaran dan dapat dipertanggungjawabkan (Sauro, 2011). Untuk itu, dalam melakukan evaluasi tingkat kebergunaan (usability) aplikasi administrasi penduduk desa yang ada di Kabupaten Ogan Ilir, digunakan SUS sebagai model evaluasi. Hal ini dilakukan dengan harapan agar dapat menggambarkan dengan jelas tingkat kebergunaan yang sebenarnya dan menjadi masukan bagi pengembangan bagi Dinas PMD Kabupaten Ogan Ilir jika akan melakukan perbaikan aplikasi.

\section{Metode Penelitian}

\subsection{Objek Penelitian}

Objek yang menjadi bahan evaluasi adalah aplikasi administrasi penduduk desa. Aplikasi ini bersifat stand alone atau dapat diakses melalui jaringan lokal dengan cara mengakses tautan http://admnistrasidesa.id. Tampilan utama dari aplikasi ini berupa halaman login bagi petugas desa seperti yang diperlihatkan pada Gambar 1. Aplikasi ini telah didistribusikan oleh Dinas PMD Kabupaten Ogan Ilir ke desa-desa di lingkungan Kabupaten Ogan Ilir. Aplikasi administrasi penduduk desa ini diletakkan pada komputer desa yang dikelola oleh petugas desa. Pengguna yang dapat mengakses aplikasi ini hanya petugas yang ditentukan oleh pihak Dinas PMD Kabupaten Ogan Ilir, yaitu kepala desa atau sekretraris desa.

Aplikasi administrasi penduduk desa ini memiliki fitur buku penduduk, produk unggulan, dan administrasi umum. Buku penduduk berisikan informasi yang terdiri atas data penduduk, mutasi data penduduk, penduduk sementara, dan import data penduduk. Sementara, administrasi umum berisikan 
informasi tentang peraturan desa, keputusan kepala desa, aparat desa, dan ekspedisi. Gambaran singkat mengenai fitur aplikasi administrasi penduduk desa disajikan pada Gambar 2.

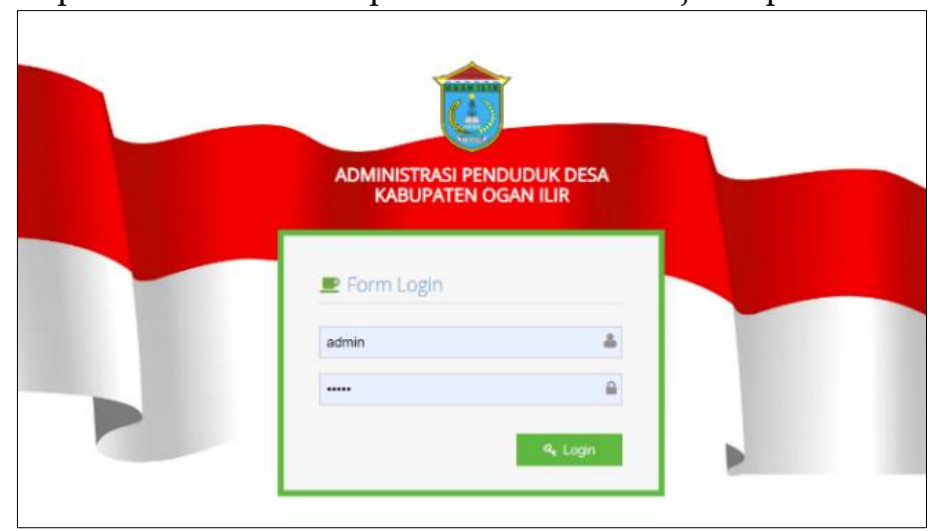

Gambar 1. Tampilan awal aplikasi administrasi penduduk desa

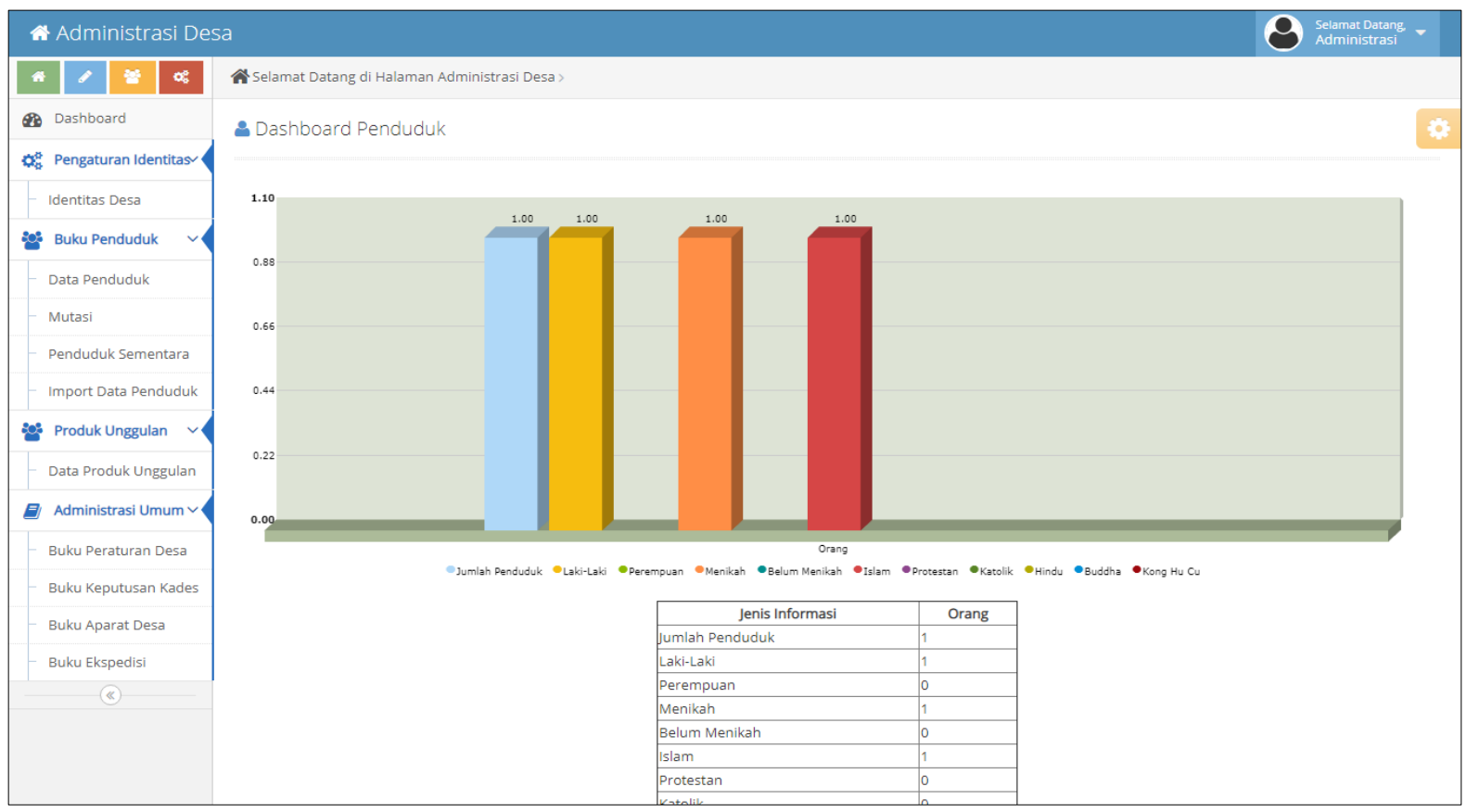

Gambar 2. Tampilan dashboard aplikasi administrasi penduduk desa

\subsection{Populasi dan Sampel}

Populasi merupakan objek yang memiliki karateristik sesuai dengan ketetapan bagi seorang peneliti untuk dipelajari dan sebagai dasar pengambilan kesimpulan (Muktar, Mukeri, \& Hasiholan, 2018). Populasi pada penelitian ini adalah semua desa di Kabupaten Ogan Ilir yang terdiri atas 237 desa dalam 17 kecamatan yang diwakili oleh kepala desa (kades) atau ssekretaris desa (sekdes). Evaluasi kebergunaan aplikasi administrasi penduduk desa ini ditentukan jumlah sampel sebagai responden evaluasi. Sampel teknik yang digunakan adalah teknik probability sampling dengan pendekatan proportionate stratified random sampling. Teknik ini sebenarnya memiliki kesamaan dengan simple random sampling. Akan tetapi, yang membedakannya adalah probability sampling dengan pendekatan proportionate stratified random sampling dalam menentukan sampel lebih memperhatikan strata populasi. Perhitungan penentukan jumlah sampel menggunakan formula Slovin. Populasi dalam evaluasi kebergunaan aplikasi administrasi penduduk ini berjumlah 237 orang yang mewakili 1 orang setiap desa dan presisi yang ditetapkan atau tingkat signifikansi 0,05; maka besarnya sampel pada penelitian ini dapat ditentukan berdasarkan Persamaan 1,

$n=\frac{N}{1+N e}$

di mana $n$ adalah jumlah sampel, $N$ adalah jumlah populasi, dan $e$ adalah error level, umumnya digunakan $1 \%$ atau 0,$01 ; 5 \%$ atau 0,05 ; dan $10 \%$ atau 0,1 .

Evaluasi tingkat kebergunaan aplikasi Administrasi Penduduk menggunakan ... (c) 2019 Register: Jurnal IImiah Teknologi Sistem Informasi. Semua hak cipta dilindungi undang-undang. 


$$
n=\frac{237}{1+237(0,05)^{2}}=\frac{237}{1+(238 \times 0,0025)}=\frac{237}{1+0,5925}=148,8=149
$$

Setelah diketahui jumlah sampel untuk melakukan evaluasi, maka selanjutnya adalah menentukan level strata responden. Untuk menentukan jumlah level strata yang digunakan berdasarkan jabatan, diambil dari karateristik responden. Jabatan responden yang ada yaitu kades dan sekdes yang terdiri atas 167 kades dan 60 sekdes. Berikut dapat diketahui jumlah masing-masing responden untuk masing-masing level strata.

$$
\begin{aligned}
& \text { 1. } \text { Kades }=\left(\frac{167}{237}\right) \times 149=104,992=105 \text { responden } \\
& \text { 2. Sekdes }=\left(\frac{70}{237}\right) \times 149=44,008=44 \text { responden }
\end{aligned}
$$

\subsection{Metode Evaluasi}

Evaluasi tingkat kebergunaan aplikasi administrasi penduduk desa pada Kabupaten Ogan Ilir dilakukan dengan mengungkapkan fenomena-fenomena dan fakta yang terjadi. Dengan demikian, metode penelitian yang digunakan adalah metode kualitatif (Ependi, 2016). Di dalam penelitian ini akan dijelaskan pandangan pengguna terhadap aplikasi administrasi penduduk desa berdasarkan pengalaman yang dirasakan ketika menggunakan aplikasi. Pengguna yang dijadikan responden dalam evaluasi kebergunaan aplikasi administrasi penduduk desa ini adalah kades atau sekdes. Untuk melakukan evaluasi tahapan-tahapan yang dilakukan, dimulai dari penentuan skenario penggunaan aplikasi, penentuan jumlah responden, pengumpulan data, dan analisis data seperti yang diperlihatkan pada Gambar 3.

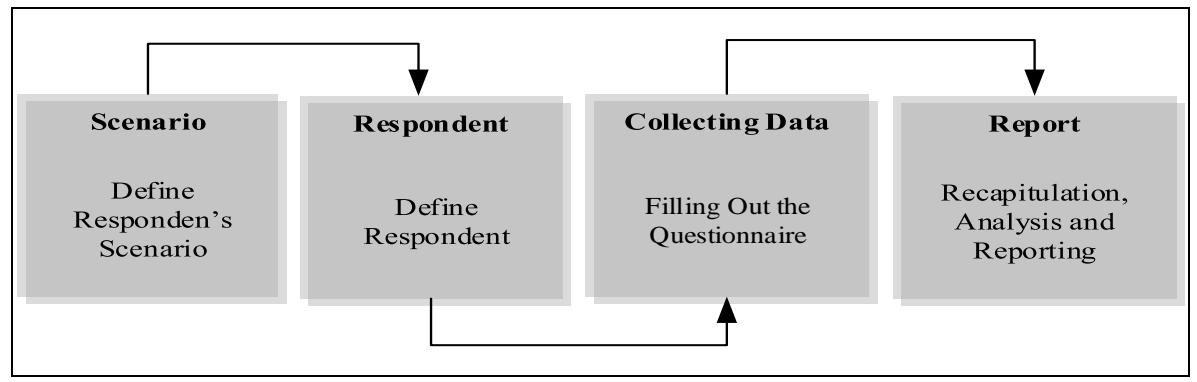

Gambar 3. Tahapan penelitian evaluasi kebergunaan SUS (Ependi, Panjaitan, \& Hutrianto, 2017)

Tabel 1. Instrumen System Usability Scale

\begin{tabular}{|c|l|c|}
\hline No. & \multicolumn{1}{|c|}{ Pernyataan } & Skala \\
\hline 1 & $\begin{array}{l}\text { I think that I would like to use this system frequently (Saya pikir bahwa saya akan menginginkan } \\
\text { lebih sering menggunakan aplikasi ini) }\end{array}$ & $1 \mathrm{~s} / \mathrm{d} 5$ \\
\hline 2 & $\begin{array}{l}\text { I found the system unnecessarily complex. (Saya menemukan bahwa aplikasi ini, tidak harus dibuat } \\
\text { serumit ini) }\end{array}$ & $1 \mathrm{~s} / \mathrm{d} 5$ \\
\hline 3 & $\begin{array}{l}\text { I thought the system was easy to use (Saya pikir aplikasi mudah untuk digunakan) } \\
\text { saya akan membutuhkan bantuan dari orang teknis untuk dapat menggunakan aplikasi ini) }\end{array}$ & $1 \mathrm{~s} / \mathrm{d} 5$ \\
\hline 5 & $\begin{array}{l}\text { I found the various functions in this system were well integrated (Saya menemukan berbagai fungsi } \\
\text { di aplikasi ini diintegrasikan dengan baik) }\end{array}$ & $1 \mathrm{~s} / \mathrm{d} 5$ \\
\hline 6 & $\begin{array}{l}\text { I thought there was too much inconsistency in this system (Saya pikir ada terlalu banyak } \\
\text { ketidakkonsistenan dalam aplikasi ini) }\end{array}$ & $1 \mathrm{~s} / \mathrm{d} 5$ \\
\hline 7 & $\begin{array}{l}\text { I would imagine that most people would learn to use this system very quickly (Saya bayangkan bahwa } \\
\text { kebanyakan orang akan mudah untuk mempelajari aplikasi ini dengan sangat cepat) }\end{array}$ & $1 \mathrm{~s} / \mathrm{d} 5$ \\
\hline 8 & $\begin{array}{l}\text { I found the system very cumbersome to use (Saya menemukan, aplikasi ini sangat rumit untuk } \\
\text { digunakan) }\end{array}$ & $1 \mathrm{~s} / \mathrm{d} 5$ \\
\hline 9 & $\begin{array}{l}\text { Ifelt very confident using the system (Saya merasa sangat percaya diri untuk menggunakan aplikasi } \\
\text { ini) }\end{array}$ & $1 \mathrm{~s} / \mathrm{d} 5$ \\
\hline 10 & $\begin{array}{l}\text { Ineeded to learn a lot of things before I could get going with this system (Saya perlu belajar banyak hal } \\
\text { sebelum saya bisa memulai menggunakan aplikasi) }\end{array}$ & $1 \mathrm{~s} / \mathrm{d} 5$ \\
\hline
\end{tabular}

Gambar 3 memiliki empat fase. Fase pertama, pembuatan skenario untuk dijalankan oleh pengguna ketika melakukan evaluasi. Fase kedua, penentuan responden dan jumlah responden yang 
menjadi sumber daya dalam melakukan evaluasi. Fase ketiga, pengumpulan data menggunakan kuesioner sesuai dengan instumen SUS. Fase keempat, pembuatan rekapitulasi dan pelaporan. Dalam fase ini dilakukan perekapan data dan analisis data untuk disajikan sebagai hasil evaluasi. Sesuai proses penelitian yang diperlihatkan pada Gambar 3, evaluasi kebergunaan menggunakan SUS terhadap aplikasi administrasi penduduk desa, instrumen evaluasi dengan SUS seperti yang diperlihatkan pada Tabel 1 dengan sepuluh instrumen (Nielsen, 1994). Sementara, skala jawaban yang dimiliki yaitu dari 1 sampai dengan 5: 1 berarti sangat tidak setuju (strongly disagree), 2 berarti tidak setuju (disagree), 3 berarti agak setuju (somewhat agree), 4 berarti setuju (agree), dan 5 sangat setuju (strongly agree). Untuk melakukan perhitungan hasil evaluasi dengan instrumen SUS, terdapat aturan tersendiri dengan ketentuan sebagai berikut (Sauro, 2011).

1. Instrumen nomor ganjil skala jawaban dikurangi 1

2. Instrumen nomor genap skala jawaban dikurangi 5

3. Skala 0 sampai dengan 4 (empat respon paling positif)

4. Menjumlahkan skala jawaban dan dikali 2,5

5. Menentukan rerata jawaban instrumen

Proses akhir dari evaluasi kebergunaan dengan SUS adalah penentuan kesimpulan hasil. Untuk melakukan penentuan kesimpulan terdapat tiga aspek utama, yaitu acceptability, grade scale, dan adjective rating seperti yang diperlihatkan pada Gambar 4. Acceptability adalah aspek yang menentukan penerimaan aplikasi dengan tingkat acceptability yang terdiri atas 1) not acceptable, 2) marginal (low dan hoght), dan 3) acceptable. Grade scale merupakan aspek yang menentukan tingkat kualitas aplikasi yang terdiri atas grade scale A, B, C, D, dan E. Adjective rating merupakan aspek yang menentukan rating kebergunaan aplikasi. Adjective rating terdiri atas beberapa tingkat, yaitu 1) worst imaginable, 2) poor, 3) ok, 4) good, 5) excellent, dan 6) best imaginable (Sauro, 2011). Penentuan hasil evaluasi aplikasi menggukanan acceptability, grade scale, dan adjective rating dilakukan berdasarkan hasil rekapitulasi nilai berupa nilai komulatif rerata instrumen, bukan nilai masing-masing instrumen evaluasi. Penentuan kesimpulan juga dapat dilakukan hanya dengan grade scale melalui ketentuan untuk rerata sebagai berikut (Bangor, Kortum, \& Miller, 2009).

1. Grade $A \geq 80,3$

2. $74 \leq$ grade $B<80,3$

3. $68 \leq$ grade $C<74,3$

4. $51 \leq$ grade $D<68$

5. Grade $F<51$

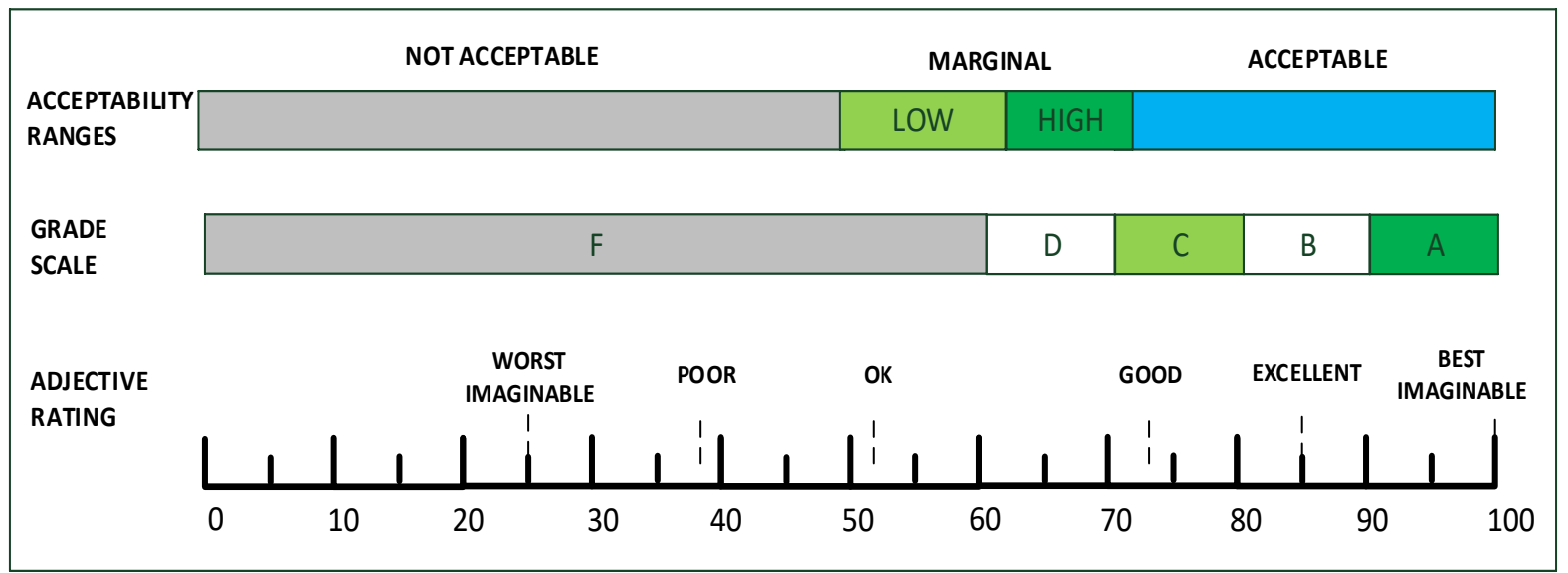

Gambar 4. Penentuan hasil valuasi kebergunaan dengan SUS (Tullis \& Stetson, 2004)

\section{Hasil dan Pembahasan}

Sesuai dengan metode penelitian yang telah dijelaskan, hasil penelitian evaluasi kebergunaan aplikasi administrasi penduduk desa studi kasus Kabupaten Ogan Ilir dapat dijelaskan sebagai berikut.

\subsection{Karateristik Responden}


Karateristik responden merupakan elemen penting dari evaluasi kebergunaan aplikasi administrasi penduduk desa Kabupaten Ogan Ilir. Karateristik responden yang menjadi atribut adalah tingkat pendidikan, jabatan, lama menjabat, dan jenis kelamin. Berikut dapat dilihat karateristik reponden.

a. Tingkat Pendidikan Responden

Tingkat pendidikan merupakan salah satu syarat bagi seseorang jika ingin menjadi kades atau sekdes. Tingginya tingkat pendidikan akan menjadi nilai tambah bagi masyarakat desa dalam melakukan pemilihan kades atau pengangkatan sekdes. Tingkat pendidikan dapat berpengaruh besar dalam gaya kepememimpinan seorang kades. Tingkat pendidikan juga akan mempengaruhi pola pikir dalam bekerja. Untuk itu, dalam evaluasi kebergunaan aplikasi administrasi penduduk desa ini dapat diketahui bahwa responden dengan tingkat pendidikan Sekolah Menengah Pertama (SMP) sebanyak 34 responden atau 23\%, tingkat pendidikan Sekolah Menengah Atas (SMA) sebanyak 107 responden atau 72\%, dan tingkat pendidikan Strata 1 (S-1) sebanyak 7 responden atau 5\%. Ilustrasi tingkat pendidikan responden disajikan pada Gambar 5.

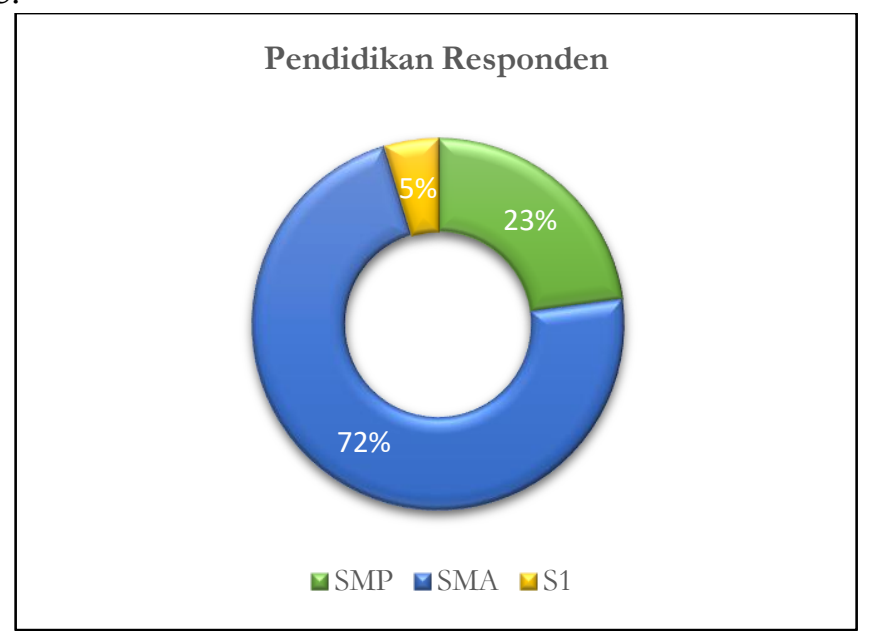

Gambar 5. Pendidikan responden

b. Jabatan Responden

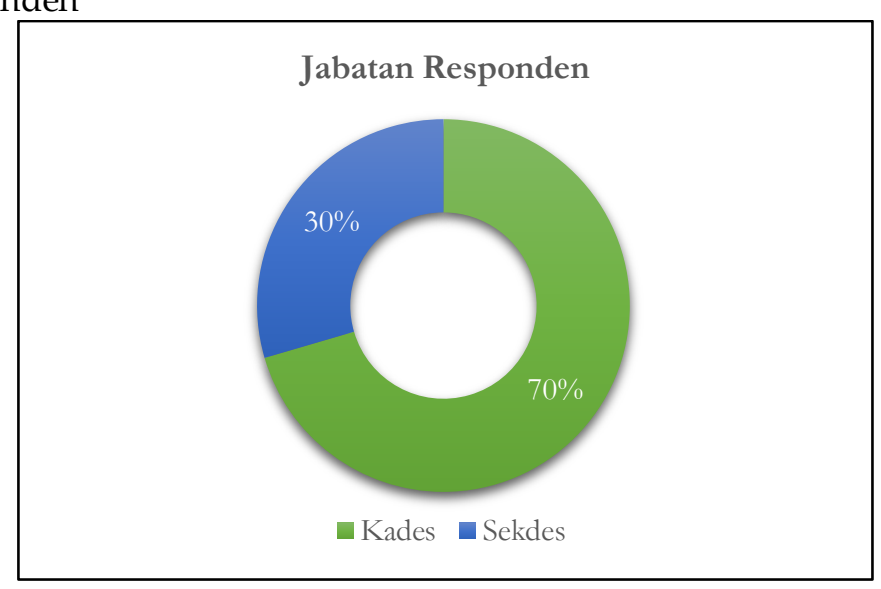

Gambar 6. Jabatan responden

Karateristik responden yang kedua adalah jabatan. Dalam evaluasi kebergunaan aplikasi administrasi penduduk, pada jabatan responden terdapat dua jenis, yaitu kades dan sekdes. Namun, dalam melakukan evaluasi ini, yang menjadi responden adalah salah satu saja dari masing-masing desa. Untuk itu, dapat diketahui bahwa jabatan responden yang memberikan tanggapan dalam evaluasi aplikasi ini terdiri atas 44 responden yang menjabat sebagai sekdes atau sama dengan 30\% dan 105 responden yang menjabat sebagai kades atau sama dengan $70 \%$, seperti yang diperlihatkan pada Gambar 6. Dari 105 responden dengan strata level kades, sebaran tingkat pendidikan sebanyak 2\% sarjana, 7\% tingkat pendidikan SMP, dan 91\% tingkat pendidikan SMA. Kondisi tersebut menunjukkan bahwa kades yang menjabat mayoritas berpendidikan SMA. Selanjutnya, dari 44 responden dengan strata level sekdes, sebaran tingkat pendidikan $29 \%$ berpendidikan SMP, $65 \%$ berpendidikan SMA, dan $6 \%$ berpendidikan sarjana. 
Kondisi tesebut menunjukkan bahwa mayoritas sekdes yang menjadi responden berpendidikan SMA.

c. Lama Menjabat dan Jenis Kelamin

Dari strata level responden seperti yang diperlihatkan pada Gambar 6 yang terdiri atas kades dan sekdes, maka dapat diketahui lama menjabat bervaratif, seperti yang terlihat pada Gambar 7. Lama menjabat, baik kades dan sekdes dapat diketahui bahwa: 1) menjabat selama 1 tahun sebesar $9 \%$, 2) menjabat selama 2 tahun sebesar $72 \%$, 3) menjabat selama 3 tahun sebesar 3\%, 4) menjabat selama 4 tahun sebesar 1\%, dan 5) menjabat selama 5 tahun sebesar $15 \%$.

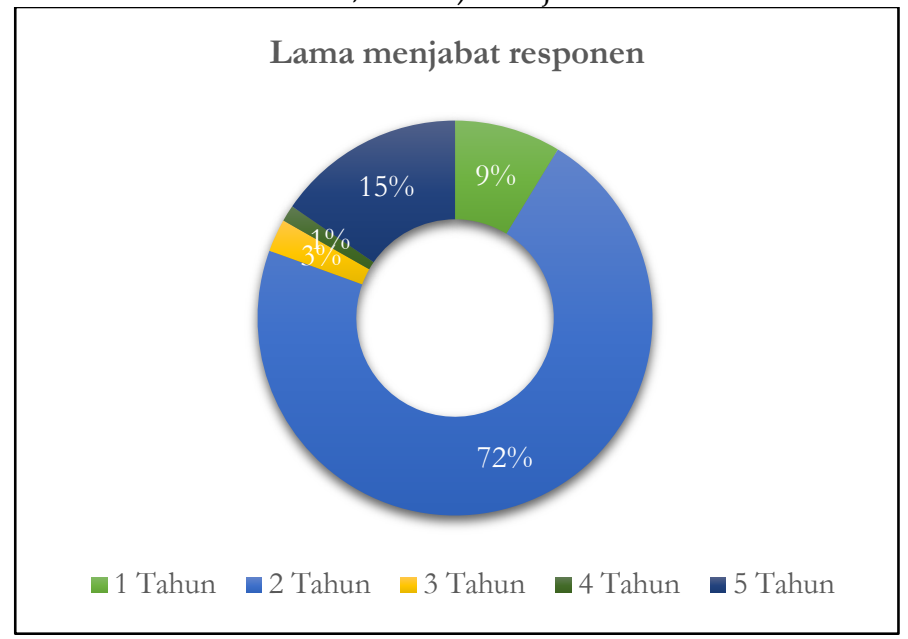

Gambar 7. Lama menjabat responden

\subsection{Nilai Kebergunaan Setiap Instrumen}

Nilai kebergunaan instrumen merupakan nilai yang diberikan oleh responden untuk masing-masing instrumen SUS. Dalam SUS terdapat sepuluh instrumen untuk melakukan evaluasi. Setiap jawaban responden pada nomor ganjil dan nomor genap akan memiliki hasil yang berbeda yang disebabkan aturan dalam perhitungan skala jawaban. Ketentuan dalam perhitungan SUS tersebut yaitu 1) setiap jawaban yang diberikan oleh responden pada instrumen dengan nomor pernyataan ganjil, skala jawaban responden dikurangi dengan 1 (satu); 2) setiap jawaban yang diberikan oleh responden pada instrumen dengan nomor pernyataan genap, skala jawaban responden dikurangi 5 (lima); 3) hasil penghitungan pada poin 1 dan poin 2 akan mendapatkan skala jawaban dari 0 sampai 4 , yang berarti 4 jawaban yang positif; 4) pencarian nilai rata-rata dari total nilai instrumen yang kemudian dikalikan dengan 2,5; dan 5) penentuan kesimpulan dari hasil evaluasi kebergunaan (usability) berdasarkan hasil pada poin 4. Untuk itu, dapat diketahui hasil rekapitulasi skala jawaban yang diberikan responden dalam evaluasi kebergunaan dengan SUS seperti yang diperlihatkan pada Tabel 2.

Tabel 2. Rekapitulasi jawaban responden

\begin{tabular}{ccccccc}
\hline \multirow{2}{*}{ No } & \multicolumn{7}{c}{ Skala Jawaban Responden } & \multicolumn{2}{c}{ Responden } \\
\cline { 2 - 6 } & $\mathbf{1}$ & $\mathbf{2}$ & $\mathbf{3}$ & $\mathbf{4}$ & $\mathbf{5}$ & 149 \\
\hline P1 & 0 & 0 & 0 & 58 & 91 & 149 \\
P2 & 73 & 72 & 4 & 0 & 0 & 149 \\
P3 & 0 & 0 & 1 & 65 & 83 & 149 \\
P4 & 86 & 63 & 0 & 0 & 0 & 149 \\
P5 & 0 & 0 & 0 & 56 & 93 & 149 \\
P6 & 65 & 84 & 0 & 0 & 0 & 149 \\
P7 & 0 & 0 & 0 & 66 & 83 & 149 \\
P8 & 62 & 87 & 0 & 0 & 0 & 149 \\
P9 & 0 & 0 & 0 & 66 & 83 & 149 \\
P10 & 72 & 73 & 4 & 0 & 0 & . \\
\hline
\end{tabular}

Sesuai dengan data jawaban responden yang diperlihatkan pada Tabel 2, dilakukan penghitungan sesuai ketentuan SUS pada poin 1 dan poin 2. Maka, didapat hasil rekapitulasi data jawaban responden seperti yang diperlihatkan pada Tabel 3. Data jawaban responden yang diperlihatkan pada Tabel 3 merupakan data rekapitulasi 
jawaban yang telah dilakukan penghitungan dengan menggunakan ketentuan SUS. Untuk itu, dapat dijelaskan pandangan responden terhadap aplikasi administrasi penduduk desa Kabupaten Ogan Ilir berdasarkan masingmasing instrumen.

a. Saya pikir bahwa saya akan/ingin lebih sering menggunakan aplikasi ini

Pernyataan pertama ini berkaitan dengan keinginan responden untuk menggunakan aplikasi secara rutin. Pada pernyataan ini, sebanyak 58 atau 39\% responden memberikan penilaian 3 dan sebanyak 91 atau 61\% responden memberikan penilaian 4 seperti yang diperlihatkan pada Gambar 8. Jawaban responden menunjukkan bahwa mayoritas responden menyatakan setuju jika aplikasi akan digunakan secara rutin (lebih sering) dalam kegiatan administrasi penduduk desa.

Dari hasil penilaian responden, dapat diketahui bahwa pada instrumen "Saya pikir bahwa saya akan/ingin lebih sering menggunakan aplikasi ini" mendapatkan nilai rerata 3,6 dari 149 responden setelah dilakukan penghitungan dengan metode SUS. Nilai rerata 3,6 menunjukkan bahwa aplikasi administrasi penduduk desa mendapatkan nilai positif atau responden setuju dengan pernyataan instrumen.

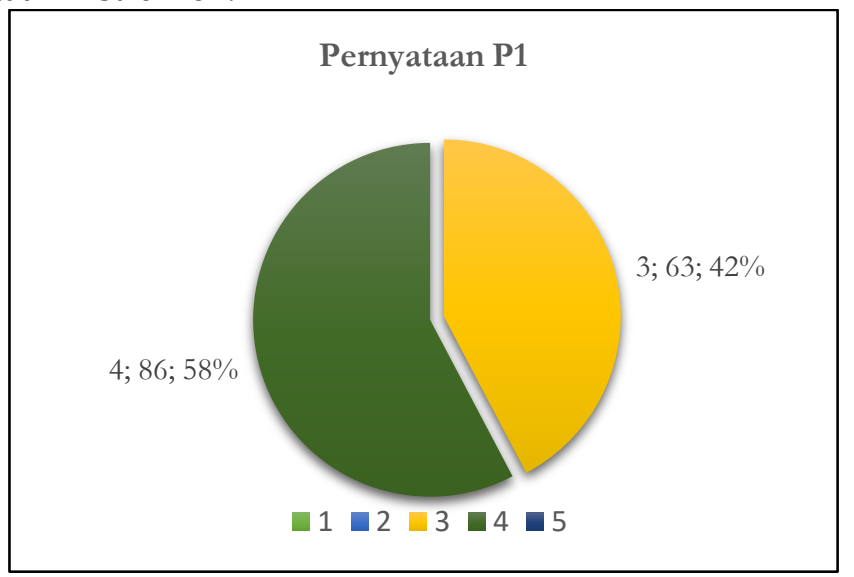

Gambar 8. Penyataan 1 instrumen SUS

Tabel 3. Rekapitulasi jawaban responden

\begin{tabular}{|c|c|c|c|c|c|c|c|}
\hline \multirow{2}{*}{ No } & \multicolumn{5}{|c|}{ Skala Jawaban Responden SUS } & \multirow{2}{*}{ Responden } & \multirow{2}{*}{ Rerata Nilai } \\
\hline & 1 & 2 & 3 & 4 & 5 & & \\
\hline P1 & 0 & 0 & 58 & 91 & 0 & 149 & 3.6 \\
\hline $\mathrm{P} 2$ & 0 & 4 & 72 & 73 & 0 & 149 & 3.5 \\
\hline P3 & 0 & 1 & 65 & 83 & 0 & 149 & 3.6 \\
\hline $\mathrm{P} 4$ & 0 & 0 & 63 & 86 & 0 & 149 & 3.6 \\
\hline P5 & 0 & 0 & 56 & 93 & 0 & 149 & 3.6 \\
\hline P6 & 0 & 0 & 84 & 65 & 0 & 149 & 3.4 \\
\hline P7 & 0 & 0 & 66 & 83 & 0 & 149 & 3.6 \\
\hline P8 & 0 & 0 & 87 & 62 & 0 & 149 & 3.4 \\
\hline P9 & 0 & 0 & 66 & 83 & 0 & 149 & 3.6 \\
\hline P10 & 0 & 4 & 73 & 72 & 0 & 149 & 3.5 \\
\hline
\end{tabular}

b. Saya menemukan bahwa aplikasi ini, tidak harus dibuat serumit ini

Instrumen dengan pernyataan "Saya menemukan bahwa aplikasi ini, tidak harus dibuat serumit ini" merupakan instrumen dengan nomor genap. Pada instrumen dengan nomor genap, semakin kecil skala penilaian yang diberikan responden, penilaian akan semakin baik. Dapat diketahui bahwa untuk instrumen ini sebanyak 73 responden memberikan penilaian 1, yang berarti sangat tidak setuju dengan pernyataan; 72 responden memberikan nilai 2 yang berarti responden tidak setuju dengan penyataan; dan 4 responden memberikan nilai 3 yang berarti responden setuju dengan pernyataan. Dari data jawaban responden dapat diketahui bahwa mayoritas responden menyatakan sangat tidak setuju dan tidak setuju dengan pernyataan instrumen. Selanjutnya, berdasarkan penilaian responden tersebut, dilakukan penghitungan dengan instrumen SUS. Penghitungan dengan SUS dilakukan sesuai dengan 
poin 2 yang menyatakan bahwa setiap penyataan dengan nomor genap, maka 5 dikurangi dengan skala jawaban responden. Untuk itu, setelah dilakukan penghitungan, dapat diketahui bahwa 145 responden atau sama dengan 97\% responden memberikan nilai positif dengan nilai empat dan tiga, 4 responden atau sama dengan 3\% responden memberikan penilaian dua dengan nilai rerata 3,5. Sebaran jawaban responden dapat dilihat pada Gambar 9.

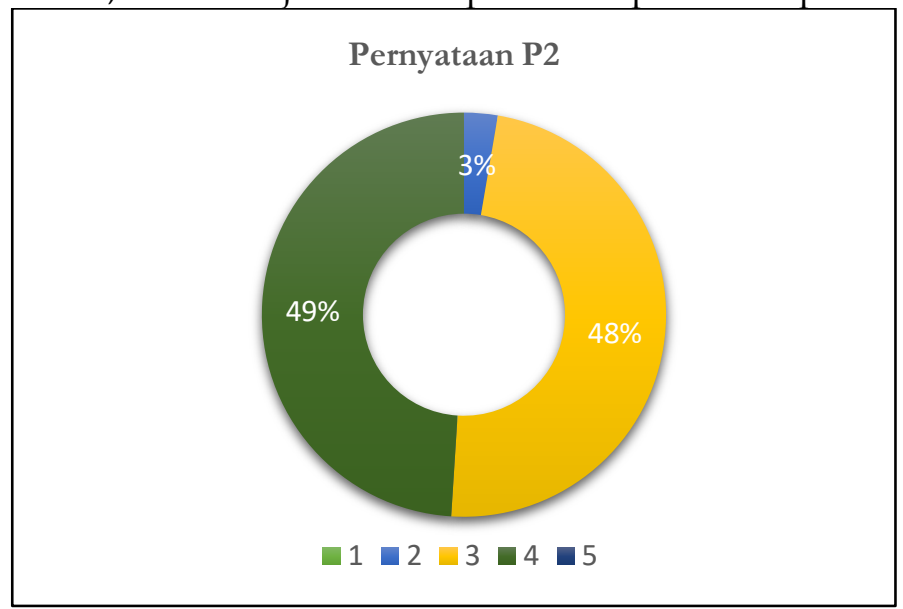

Gambar 9. Pernyataan 2 instrumen SUS

c. Saya pikir aplikasi mudah untuk digunakan

Pernyataan ketiga adalah pernyataan yang berkaitan dengan kemudahan dalam menggunakan aplikasi administrasi penduduk desa di Kabupaten Ogan Ilir. Pada pernyataan ini, mayoritas responden memberikan nilai positif seperti yang diperlihatkan pada Tabel 2, yakni 83 responden sangat setuju dengan pernyataan, 65 responden setuju dengan pernyataan, dan 1 responden agak setuju dengan pernyataan. Dengan demikian, dapat diketahui bahwa sebagian besar responden menganggap aplikasi administrasi penduduk desa mudah untuk digunakan seperti yang diperlihatkan pada Tabel 3 setelah dilakukan perhitungan SUS. Sebaran responden setelah dilakukan perhitungan SUS terdiri atas 58\% responden memberikan nilai 4 , yang berarti sangat positif; $43 \%$ responden memberikan nilai 3 yang berarti positif, dan $1 \%$ memberikan nilai 2 yang berarti agak positif seperti yang diperlihatkan pada Gambar 10.

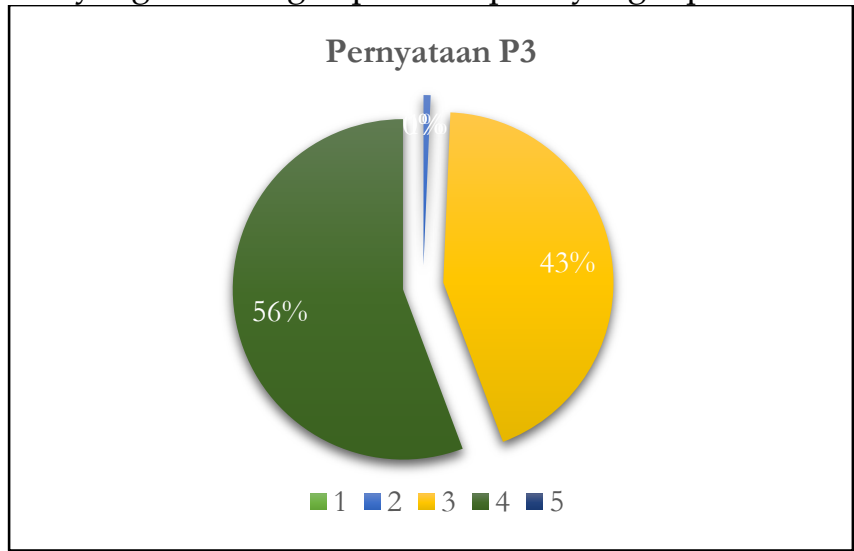

Gambar 10. Pernyataan 3 instrumen SUS

d. Saya pikir bahwa saya akan membutuhkan bantuan dari orang teknis untuk dapat menggunakan aplikasi ini

Pernyataan "Saya pikir bahwa saya akan membutuhkan bantuan dari orang teknis untuk dapat menggunakan aplikasi ini" adalah pernyataan kebutuhan bantuan secara teknis dalam menggunakan aplikasi oleh responden. Pada pernyataan ini, responden memberikan skala jawaban 1 dan 2. Sebanyak 86 (58\%) responden memberikan penilaian 1 yang berarti sangat tidak setuju dengan pernyataan dan $63(42 \%)$ responden memberikan penilaian 2 yang berarti tidak setuju dengan pernyataan. Berdasarkan skala jawaban yang diberikan responden menunjukkan bahwa responden memberikan penilaian yang positif, dibuktikan dengan hasil penghitungan dengan ketentuan SUS yang menunjukkan mayoritas skala jawaban responden mendapatkan nilai 4 dan 3 seperti yang diperlihatkan pada Gambar 11. 


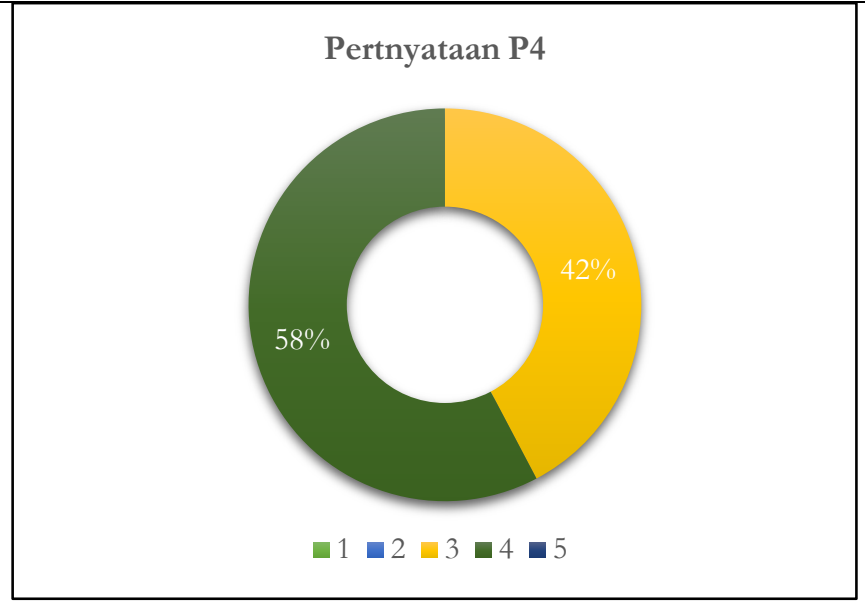

Gambar 11. Pernyataan 4 instrumen SUS

e. Saya menemukan berbagai fungsi di aplikasi ini diintegrasikan dengan baik

Pernyataan "Saya menemukan berbagai fungsi di aplikasi ini diintegrasikan dengan baik" adalah pernyataan yang berkaitan dengan integrasi fungsi (fitur) aplikasi. Pada pernyataan ini, responden memberikan respon positif yang berarti aplikasi administrasi penduduk desa telah dibuat secara terintegrasi, baik dilihat dari fungsi maupun fitur. Respons positif tersebut sesuai dengan data jawaban responden setelah dilakukan penghitungan SUS yang menunjukkan bahwa $64 \%$ jawaban responden dengan nilai 4 dan 38\% jawaban responden dengan nilai 3 . Nilai 4 berarti nilai paling positif seperti yang terlihat pada Gambar 12 .

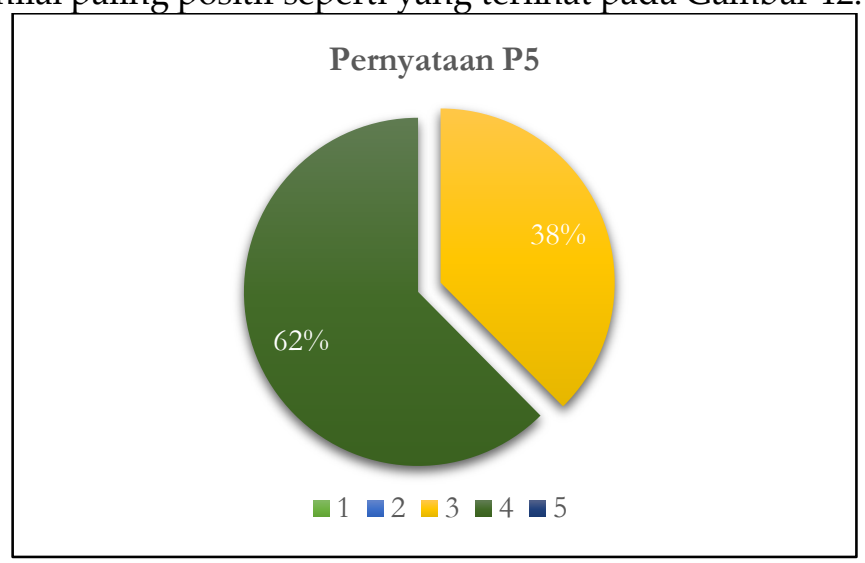

Gambar 12. Pernyataan 5 instrumen SUS

f. Saya pikir ada terlalu banyak ketidakkonsistenan dalam aplikasi ini

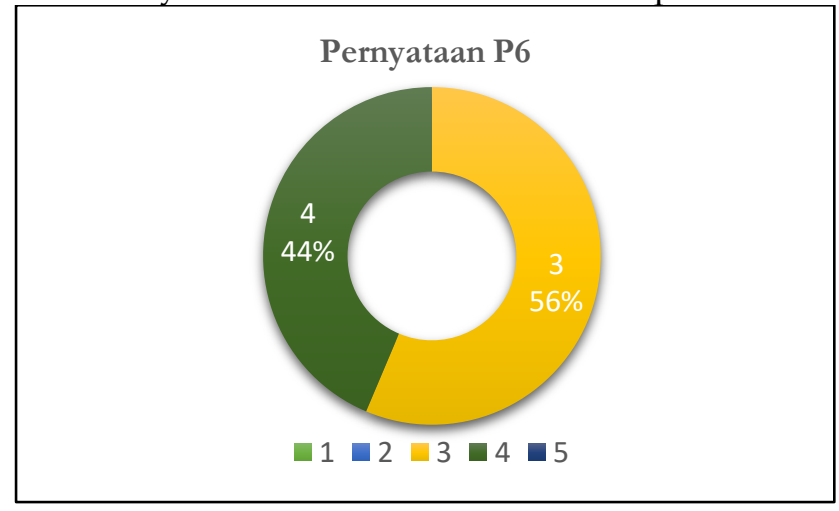

Gambar 13. Pernyataan 6 instrumen SUS

Pernyataan keenam adalah pernyataan yang berkaitan dengan konsitensi aplikasi administrasi penduduk desa di Kabupaten Ogan Ilir. Pada pernyataan ini, mayoritas responden memberikan nilai positif seperti yang diperlihatkan pada Tabel 2, yakni 65 responden sangat tidak setuju dengan pernyataan dan 84 responden tidak setuju dengan pernyataan. Dengan demikian, dapat diketahui bahwa sebagian besar responden menganggap aplikasi administrasi penduduk desa telah memiliki konsistensi, baik secara bentuk maupun warna, sehingga 
nyaman untuk digunakan. Selanjutnya, dari jawaban pernyataan 6 seperti pada Tabel 2 dilakukan penghitungan SUS seperti yang diperlihatkan pada Tabel 3. Dari hasil penghitungan dapat dibuktikan bahwa responden memberikan nilai positif yang terdiri atas $44 \%$ responden memberikan nilai 4 yang berarti sangat positif dan 56\% responden memberikan nilai 3 yang berarti positif. Sebaran jawaban responden tersebut dapat dilihat pada Gambar 13.

g. Saya bayangkan bahwa kebanyakan orang akan mudah untuk mempelajari aplikasi ini dengan sangat cepat

Pernyataan ketujuh berkaitan dengan kemudahan aplikasi untuk dipelajari. Pernyataan ini sebanyak 83 atau 56\% responden memberikan penilaian 4 dan sebanyak 66 atau $44 \%$ responden memberikan penilaian 3 seperti yang diperlihatkan pada Gambar 14. Dari jawaban responden menunjukkan bahwa mayoritas responden menyatakan setuju jika aplikasi mudah dipelajari. Dari hasil penilaian responden dapat diketahui bahwa pada pernyataan "Saya bayangkan bahwa kebanyakan orang akan mudah untuk mempelajari aplikasi ini dengan sangat cepat" mendapatkan nilai rerata 3,6 dari 149 responden setelah dilakukan penghitungan dengan metode SUS. Nilai rerata 3,6 menunjukkan bahwa aplikasi administrasi penduduk desa mendapatkan nilai positif atau responden setuju dengan pernyataan instrumen.

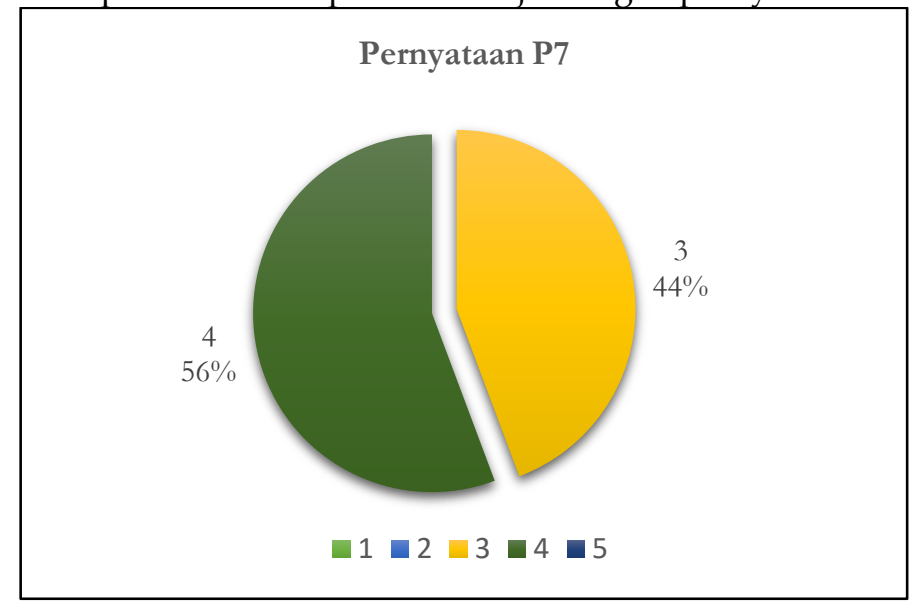

Gambar 14. Pernyataan 7 instrumen SUS

h. Saya menemukan, aplikasi ini sangat rumit untuk digunakan

Pernyataan "Saya menemukan, aplikasi ini sangat rumit untuk digunakan" adalah pernyataan yang berkaitan dengan persepsi pengguna tentang kerumitan menggunakan aplikasi administrasi penduduk desa di Kabupaten Ogan Ilir. Secara keseluruhan, penyataan ini mendapatkan nilai rerata 3,4 setelah dilakukan penghitungan SUS. Untuk jawaban responden pada pernyataan ini, mayoritas responden memberikan 3 dan 4 atau dapat dikatakan jawaban positif, yakni 66 responden memberikan jawaban 3 dan 83 memberikan jawaban 4. Untuk itu, dapat dikatakan bahwa sebagian besar responden menganggap aplikasi administrasi penduduk desa tidak rumit untuk digunakan. Sebaran jawaban responden tersebut dapat dilhat pada Gambar 15.

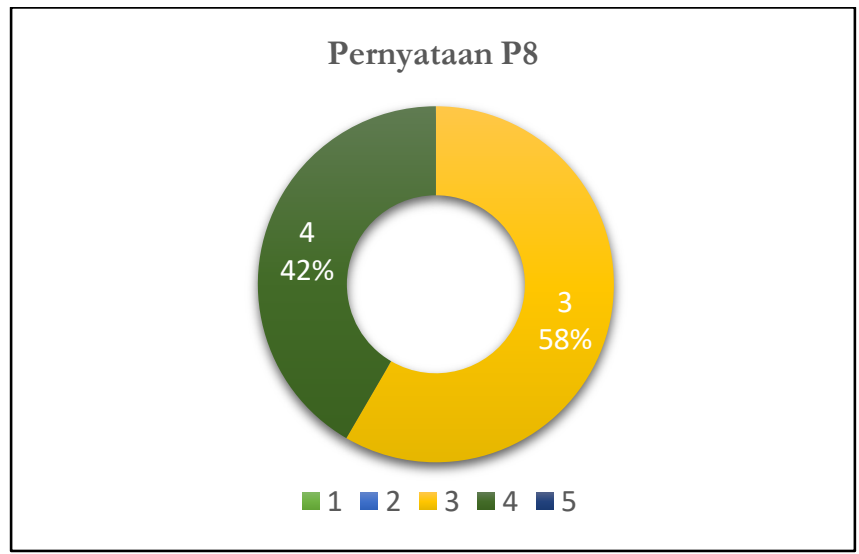

Gambar 15. Pernyataan 8 instrumen SUS

i. Saya merasa sangat percaya diri untuk menggunakan aplikasi ini 
Pernyataan kesembilan "Saya merasa sangat percaya diri untuk menggunakan aplikasi ini" adalah pernyataan yang berkaitan dengan keyakinan atau optimisme perangkat (petugas) desa untuk menggunakan aplikasi administrasi penduduk desa di Kabupaten Ogan Ilir. Pada pernyataan ini, mayoritas responden memberikan nilai positif seperti yang diperlihatkan pada Tabel 2, yakni 66 responden sangat setuju dengan pernyataan atau dengan jawaban 5 (lima) dan 83 responden setuju dengan pernyataan atau dengan jawaban 4 (empat). Dengan demikian, dapat diketahui bahwa sebagian besar responden akan menggunakan aplikasi administrasi penduduk desa dalam kegiatan administrasi penduduk. Setelah dilakukan penghitungan SUS seperti yang diperlihatkan pada Tabel 3, dapat diketahui bahwa nilai rerata untuk penyataan ini 3,4 yang berarti responden berpersepsi positif. Sebaran responden setelah dilakukan perhitungan SUS terdiri atas $56 \%$ responden memberikan nilai 4 yang berarti sangat positif dan $44 \%$ responden memberikan nilai 3 yang berarti positif seperti yang diperlihatkan pada Gambar 16. Untuk itu, dapat dikatakan bahwa pada penyataan "Saya merasa sangat percaya diri untuk menggunakan aplikasi ini" responden sepakat untuk menggunakan aplikasi administrasi penduk desa.

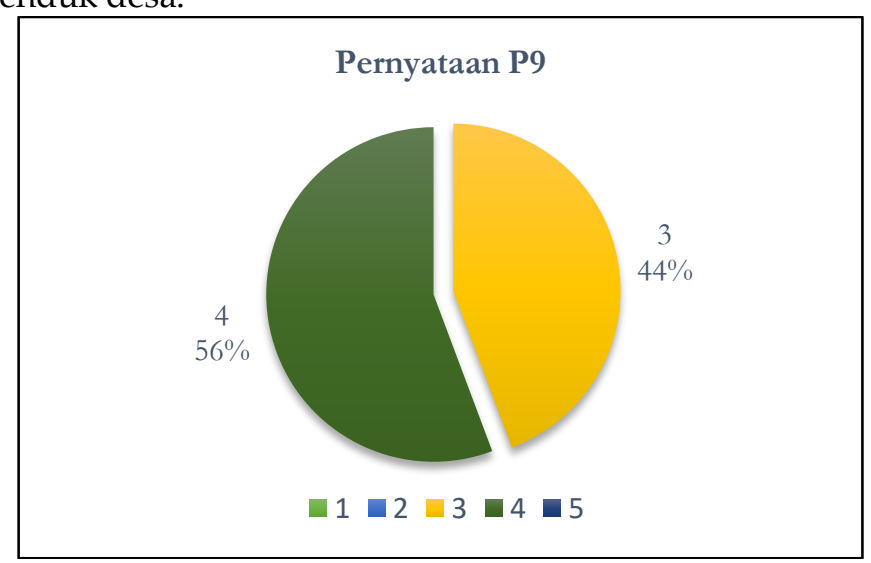

Gambar 16. Pernyataan 9 instrumen SUS

j. Saya perlu belajar banyak hal sebelum saya bisa memulai menggunakan aplikasi

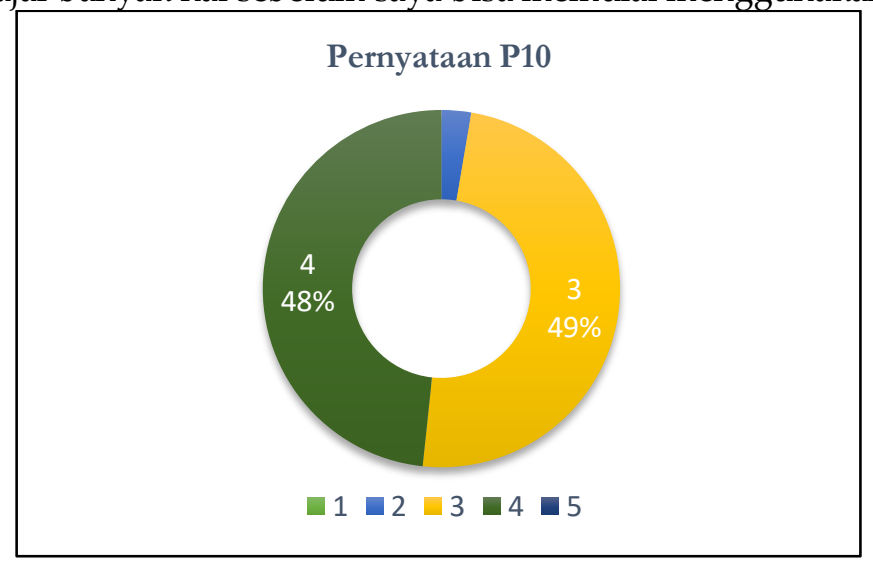

Gambar 17. Pernyataan 9 instrumen SUS

Instrumen dengan pernyataan "Saya perlu belajar banyak hal sebelum saya bisa memulai menggunakan aplikasi" merupakan instrumen dengan nomor genap. Pada instrumen dengan nomor genap, semakin kecil skala penilaian yang diberikan responden, maka penilaian akan semakin baik. Dapat diketahui bahwa, untuk instrumen ini, sebanyak 72 responden memberikan penilaian 1 yang berarti sangat tidak setuju dengan pernyataan, 73 responden memberikan nilai 2 yang berarti responden tidak setuju dengan penyataan, dan 4 responden memberikan nilai 3 yang berarti responden setuju dengan pernyataan. Dari data jawaban responden dapat diketahui bahwa mayoritas responden menyatakan sangat tidak setuju dan tidak sejutu dengan pernyataan instrumen. Selanjutnya, berdasarkan penilaian responden tersebut, maka dilakukan perhitungan dengan instrumen SUS. Penghitungan dengan SUS dilakukan sesuai dengan poin 2 yang menyatakan bahwa setiap penyataan dengan nomor genap, maka 5 dikurangi dengan skala jawaban responden. Untuk itu, setelah dilakukan 
penghitungan dapat diketahui bahwa 145 responden atau sama dengan $97 \%$ responden memberikan nilai positif dengan nilai empat dan tiga, 4 responden atau sama dengan $(3 \%)$ responden memberikan penilaian dua dengan nilai rerata 3,5 seperti yang terlihat pada Gambar 17.

\subsection{Tingkat Kebergunaan Aplikasi}

Tingkat kebergunaan adalah proses penentuan nilai akhir dari proses evaluasi kebergunaan aplikasi administrasi penduduk desa di Kabupaten Ogan Ilir. Untuk menentukan tingkat kebergunaan aplikasi, terlebih dahulu harus diketahui nilai dari penghitungan masing-masing instrumen SUS. Nilai setiap instrumen diambil dari jawaban responden yang telah dilakukan penghitungan pada Tabel 3 dan kemudian dilakukan pencarian nilai rerata masing-masing instrumen. Setelah diketahui nilai rerata setiap instrumen, hasilnya dikalikan dengan 2,5 seperti yang diperlihatkan pada Tabel 4 . Penghitungan tingkat kebergunaan juga dapat dilakukan dengan cara menjumlahkan setiap nilai rerata untuk setiap instrumen dan kemudian dikalikan 2,5.

Tabel 4. Rekapitulasi pernyataan SUS × 2,5

\begin{tabular}{ccc}
\hline No & Nilai Rerata Pernyataan $\times \mathbf{2 , 5}$ & Jumlah \\
\hline P1 & $3.6 \times 2.5$ & 9 \\
P2 & $3.5 \times 2.5$ & 8,75 \\
P3 & $3.6 \times 2.5$ & 9 \\
P4 & $3.6 \times 2.5$ & 9 \\
P5 & $3.6 \times 2.5$ & 9 \\
P6 & $3.4 \times 2.5$ & 8,5 \\
P7 & $3.6 \times 2.5$ & 9 \\
P8 & $3.4 \times 2.5$ & 8,5 \\
P9 & $3.6 \times 2.5$ & 9 \\
P10 & $3.5 \times 2.5$ & 8,75 \\
& Total Nilai SUS & $\mathbf{8 8 . 5}$ \\
\hline
\end{tabular}

Dari hasil penghitungan nilai tingkat kebergunaan yang diperlihatkan pada Tabel 4, dapat diketahui bahwa nilai atau skor dari evaluasi aplikasi administrasi penduduk desa di Kabupaten Ogan Ilir mendapatkan nilai 88,5. Dari nilai atau skor tersebut, dapat diukur sesuai ketentuan penilaian SUS seperti yang diperlihatkan pada Gambar 4. Untuk itu, dapat diketahui tingkat kebergunaan (usability) aplikasi dari tiga sisi yaitu: 1) Acceptability menilai aplikasi dari aspek penerimaan aplikasi oleh pengguna, hasil evaluasi menunjukkan bahwa aplikasi administrasi penduduk desa dikategorikan acceptable, 2) Grade Scale menilai aplikasi dari aspek tingkat kualitas, hasil evaluasi menunjukkan bahwa aplikasi administrasi penduduk desa berada pada grade scale B, dan 3) Adjective Rating memulai aplikasi dari aspek yang menentukan rating kebergunaan, hasil evaluasi menunjukkan bawah aplikasi administrasi penduduk desa dikategorikan excellent.

\section{Kesimpulan}

Evaluasi tingkat kebergunaan aplikasi administrasi penduduk desa di Kabupaten Ogan Ilir dengan metode SUS dapat disimpulkan bahwa: 1) aplikasi yang disediakan oleh Dinas PMD Kabupaten Ogan Ilir memiliki nilai kebergunaan yang tinggi sesuai hasil penilaian responden untuk masing-masing pernyataan, yaitu: Pernyataan 1 rerata nilai 3,6; Pernyataan 2 rerata nilai 3,5; pernyataan 3 rerata nilai 3,6; Pernyataan 4 rerata nilai 3,6; Pernyataan 5 rerata nilai 3,6; Pernyataan 6 rerata nilai 3,4; Pernyataan 7 rerata nilai 3,6; Pernyataan 8 rerata nilai 3,4; Pernyataan 9 rerata nilai 3,6 dan Pernyataan 10 retata nilai 3,5 atau semua instrumen (pernyataan) mendapatkan rerata nilai $>3$. Dengan demikian, aplikasi dapat difungsikan oleh perangkat desa tanpa unsur keterpaksaan dan 2) aplikasi administrasi penduduk desa dikategorikan memenuhi standar usability yang dibuktikan dari nilai acceptability, grade scale, dan adjective rating dengan nilai akhir 88,5; sehingga aplikasi tidak membutuhkan perbaikan dan dapat digunakan langsung oleh perangkat desa.

\section{Ucapan Terima Kasih}

Evaluasi tingkat kebergunaan aplikasi Administrasi Penduduk menggunakan ...

(c) 2019 Register: Jurnal IImiah Teknologi Sistem Informasi. Semua hak cipta dilindungi undang-undang. 
Terima kasih kami ucapkan kepada rekan-rekan peneliti yang telah bersama-sama melakukan penelitian ini dan juga kepada Pemerintah Kabupaten Ogan Ilir, khususnya Dinas Pemberdayaan Masyarakat dan Desa, yang telah banyak membantu selama proses penelitian ini berlangsung. Terima kasih juga kami sampaikan kepada pihak jurnal Register: Jurnal Ilmiah Teknologi Sistem Informasi yang telah meluangkan waktu untuk melakukan review terhadap artikel ini.

\section{Referensi}

Bangor, A., Kortum, P., \& Miller, J. (2009). Determining What Individual SUS Scores Mean: Adding an Adjective Rating Scale. Journal of Usability Studies (JUS), 4(3), 114-123.

Darmawan, D. (2018, Agustus 20). Pembinaan Masyarakat dan Desa Kabupaten Ogan Ilir. (U. Ependi, Interviewer) Palembang: Universitas Bina Darma.

Ependi, U. (2016). Uji Kualitas Website Dengan Instrumen Webqual(Studi Kasus: Sistem Informasi Stocking And Ordering Auto 2000 Regional Part Depo Palembang). Jurnal SISFO: Inspirasi Profesional Sistem Informasi, 5(5), 676-686.

Ependi, U., Panjaitan, F., \& Hutrianto, H. (2017). System Usability Scale Antarmuka Palembang Guide Sebagai Media Pendukung Asian Games XVIII. Journal of Information Systems Engineering and Business Intelligence (JISEBI), 3(2), 80-86.

Indonesia, R. (2014). Undang-Undang Republik Indonesia Nomor 6 Tahun 2014 Tentang Desa. Jakarta, Indonesia. Retrieved from https://spi.or.id/wp-content/uploads/2014/11/UU_NO_6_2014-Desa.pdf

Martoyo, W. U., \& Falahah, F. (2015). Kajian Evaluasi Usability dan Utility pada Situs Web. Seminar Nasional Sistem Informasi Indonesia (pp. 537-544). Surabaya: Institut Teknologi Sepuluh Nopember.

Muktar, A., Mukeri, M., \& Hasiholan, L. B. (2018). The Effect of Relationship Marketing, Quality of Service and Customer Satifaction to Customer Loyality in PT. Panelia Ekysatya Demak. Journal of Management, 4(4).

Nielsen, J. (1994). Usability Inspection Methods. Conference Companion CHI'94, (pp. 413-414). Boston,Massachusetts, USA.

Nielsen, J. (2012, January 4). Usability 101: Introduction to Usability. Retrieved from Nielsen Norman Group: https://www.nngroup.com/articles/usability-101-introduction-to-usability/

Nurhadryani, Y., Hermadi, I., \& Khotimah, H. (2013). Pengujian Usability untuk Meningkatkan Antarmuka Aplikasi Mobile. Jurnal Ilmu Komputer dan Agri-Informatika, 2(2), 83-93.

Pudjoatmodjo, B., \& Wijaya, R. (2016). Tes Kegunaan (Usabilty Testing) Pada Aplikasi Kepegawaian Dengan Menggunakan System Usabilty Scale (Studi Kasus : Dinas Pertanian Kabupaten Bandung). Seminar Nasional Teknologi Informasi dan Multimedia 2016 (pp. 2.9-37 - 2.9-42). Yogyakarta: STMIK AMIKOM Yogyakarta.

RI, K. (2017). Peraturan Menteri Keuangan Republik Indonesia Nomor 199/PMK. 07 /2017 Tentang Tata Cara Pengalokasian Dana Desa Setiap Kabupaten/Kota Dan Penghitungan Rincian Dana Desa Setiap Desa. Jakarta, Indonesia. Retrieved from https://jdih.kemenkeu.go.id/fullText/2017/199 PMK.07 2017Per.pdf

Sauro, J. (2011). A practical guide to the system usability scale: Background, benchmarks $\mathcal{E}$ best practices. Denver, Colorado: Measuring Usability.

Sauro, J. (2011, February 2). Measuring Usability With The System Usability Scale (SUS). Retrieved from Measuring U: https://measuringu.com/sus/

Susilo, E., Wiraatmaja, B. S., \& Al Fatta, H. (2017). Evaluasi Aplikasi Mobile SSP (Secure System Of Payment) menggunakan Prinsip Usability. Seminar Nasional Teknologi Informasi dan Multimedia 2017 (pp. 2.6-7 - 2.6-12). Yogyakarta: STMIK AMIKOM Yogyakarta.

Tullis, T. S., \& Stetson, J. N. (2004). A Comparison of Questionnaires for Assessing Website Usability. Usability Professionals Association (UPA) 2004 Confrence. Minneapolis, Minnesota.

usability.gov. (2018). System Usability Scale (SUS). Retrieved from usability.gov: https:/www.usability.gov/how-to-and-tools/methods/system-usability-scale.html

Xie, T., Chen, H., Li, J., \& Xiong, H. (2011). A study on the methods of software testing based on the design models. 2011 6th International Conference on Computer Science \& Education (ICCSE). Singapore, Singapore: IEEE. 